Helmut K. Anheier ${ }^{1}$ / Stefan Toepler ${ }^{2}$

\title{
Policy Neglect:The True Challenge to the Nonprofit Sector
}

\author{
${ }^{1}$ Hertie School, Berlin, Cermany, E-mail: anheier@hertie-school.org \\ ${ }^{2}$ Schar School of Policy and Government, George Mason University, 3351 Fairfax Drive, MSN 3B1 Arlington, United States of \\ America, E-mail: stoepler@gmu.edu. https://orcid.org/0000-0003-2648-6427.
}

\begin{abstract}
:
The relationship between many governments and the nonprofit sector as well as organized civil society more generally has become more complex, laden with often hidden tensions. In some cases, state-nonprofit sector relationships have deteriorated, which has led experts and activists to speak of a "shrinking space" for civil society. However, this diagnosis applies mostly to illiberal and autocratic countries. More widespread is a stagnation in state - nonprofit sector relations that seems indicative of a longstanding policy neglect, which we see as the true challenge to the future of the nonprofit sector. In response, we argue for more proactive policy stances along with a differentiated model for regulatory frameworks on the basis of functional roles.
\end{abstract}

Keywords: closing civic space, nonprofit sector, regulatory voids, policy neglect, accountability deficits DOI: $10.1515 /$ npf-2019-0041

\section{Introduction $^{1}$}

In both developed market economies and transition countries, nonprofit organizations (NPOs) have generally been growing in significance over recent decades in many respects. As providers of health, social, educational and cultural services of many kinds, they account for 5-10\% of GDP in most OECD countries (see Anheier 2014). They have also drawn increasing attention in the context of civic participation and social engagement and are frequently regarded as key sources of social innovations to address public problems. These developments are taking place across many countries that otherwise differ in their economic structures, politics, cultures and social fabrics. They are driven, in large measure, by three broad policy perspectives that position NPOs in specific ways and allocate certain roles to them.

The most prevalent one concerns NPOs as service providers. In many countries, nonprofits have long been key actors in providing all sorts of welfare services. In the context of new public management approaches, reliance on quasi-markets and competitive bidding processes has both deepened where it already existed and developed where it was minimal or even non-existent (Salamon and Toepler 2015). Expanded contracting regimes in health and social service provision, voucher programs, and public-private partnerships are examples of this development as is the recent rediscovery of co-production (Verschuere, Brandsen, and Pestoff 2012; Brandsen forthcoming). Essentially, this policy approach sees NPOs as service providers that are more efficient than state agencies, and as more trustworthy than for-profit businesses in markets where monitoring is costly and profiteering likely.

Second, NPOs can serve as cohesion builders. This perspective sees them as both builders and sustainers of social cohesion in increasingly diverse societies, strengthening the nexus between individuals' social capital and economic development. Attempts to maintain or engender a sense of community and belonging and to enhance civic mindedness and engagement by promoting volunteering and charitable giving are illustrative of this perspective. The basic assumption is that people embedded in dense networks of associational bonds are not only less prone to social problems of many kinds but also economically more productive and politically more involved (Putnam 2001).

A third perspective that has gained recent currency perceives NPOs as social innovators. This policy perspective views nonprofits as a key source of social innovation to address diverse public problems. Because they tend to be smaller in scale and closer in proximity to those affected by, or concerned with, an issue, NPOs are presumed to be better at such innovations and more creative than governments typically are. They are also the operating ground for social entrepreneurs. The policy response then is for governments to seek partnerships with NPOs to identify, test and scale up social innovations. 
Despite the very different roles that each of these policy perspectives prescribes for NPOs, it is clear that the nonprofit sector holds significant potential for social innovation, resilience, service delivery and lending voice to diverse interests and communities that are otherwise excluded. However, in some countries, NPOs operating locally, nationally and across borders are experiencing many changes and concomitant challenges (Anheier 2017). Indeed, there are growing indications that the "space" for civil society organizations is shrinking worldwide, particularly, but not exclusively, in authoritarian and hybrid regimes (Carothers and Brechenmacher 2014; Civicus 2018; ICNL 2018; USAID 2017). Shrinking or closing space refers to efforts by these governments to cut off NGOs typically promoting human or environmental rights from foreign donor support by way of regulatory and bureaucratic restrictions and suppression (Dupuy, Ron, and Prakash 2016). Shrinking space is thus mainly about repressive policies particularly directed at certain parts of civil society.

Yet more widespread is a slow erosion and stagnation that characterizes state-nonprofit sector relationships in terms of policy development, which differs from actively repressive policies and that we might term policy neglect. While the nonprofit sector and civil society have grown economically and gained in importance in many regards, they have not received the policy attention they deserve to make sure that they can fulfill the diverse expectations of the three above-mentioned perspectives:

- Increasingly part of public management approaches and operating in quasi-markets, NPOs have to work under outdated regulatory frameworks that fail to accommodate a much more diverse and expanded set of nonprofit organizations and civil society activism;

- While social entrepreneurship and social innovation are seen as essential to problem-solving, few supporting policies are in place, fewer still for vetting and scaling innovation, and investment markets are virtually absent;

- While nonprofit organizations and civil society are generally arenas of civil engagement and commitment to the common good, accountability is typically limited to fiscal matters, leaving wider responsibilities and transparency unchecked.

As a result of this policy neglect, nonprofit organizations and social entrepreneurs cannot fulfill their full potential for society; regulatory voids that emerge around pressing policy issues go unsettled and result in human suffering as well as a weakening of civil society; and accountability deficits increase the possibility of scandals and failures, and hence a loss of public trust.

\section{Policy Neglect}

Although some may believe that not drawing government attention is a good thing, the policy neglect of the nonprofit sector should not be considered a form of benign neglect, a term coined by Senator D. Patrick Moynihan in 1970, that refers to deliberate non-interference intended to benefit someone or something more than continual attention would. The currently notable neglect of civil society generally and nonprofit organizations in particular is neither intended nor beneficial, but it leans towards a general policy stagnation.

\subsection{Policy Stagnation}

Although the most well-known cases of government-led shrinking of civic space are clearly intentional, only a few governments of economically advanced countries have proactively sought to constrain civil society. ${ }^{2}$ At the same time, the gradual erosion identified by Anheier, Lang, and Toepler (2019) through consultations with civil society experts in G20 member countries suggests that most of those countries are at least not actively seeking to expand civil society space or develop the capacities of the organizations that populate it. Rather, governments more or less passively allow civil society space to slowly erode due to the impact of other policies or they let capacities deteriorate through lack of reform.

The clearest case of the former are the efforts of the inter-governmental Financial Action Task Force to curb support of international money laundering and financing of terrorism. Despite recent (2016) clarification that not all nonprofit organizations should be considered high risk, the rules have effectively hindered or even cut off access by many organizations to banking and other financial services, with significant consequences especially for internationally active nonprofit organizations (Daigle, Toepler, and Smock 2016; Eckert, Guinane, and Hall 2017). Nearly all civil society experts consulted in Anheier, Lang and Toepler's (2019) research were at least somewhat concerned about the effects of anti-terrorism related legislation on civil society space. 
Furthermore, the implementation of new public management approaches, even if not specifically focused on nonprofit organizations, has had an arguably profound effect, especially on service providers. For example, in the UK, the US, and elsewhere, the pressures of competing in quasi-markets and the intricacies of contracting arrangements have led to commercialization and professionalization and have brought into question the identity and autonomy of many nonprofit service-providing organizations (Toepler 2018a).

As noted, lack of reform is another way civic space and civil society capacity erode. An example is Germany, where public benefit laws designed for the realities of the late nineteenth and early twentieth centuries are extremely outdated, and reform efforts to modernize the current system, though on the political agenda for two decades, are still outstanding (Strachwitz 2018). Civil society experts confirmed the need for review and reform of Germany's regulatory framework, including legal forms and tax exemption rules, and cautioned that inaction could threaten future civil society-state relations (Anheier, Lang, and Toepler 2019).

Regulatory complexity and bureaucracy remain burdensome for civil society in many countries. In Italy, for example, though some measures have been taken to legally recognize new organizational forms such as social enterprises, the bureaucratic requirements for most nonprofit organizations have not been reduced and continue to strain organizational capacities. Experts in Argentina and Japan likewise pointed to the complexity and fragmentation of regulatory frameworks as areas of long-needed reform (see Anheier, Lang, and Toepler 2019, Appendix I for a summary of G20 expert assessments).

Even when not outrightly repressed, the work of NPOs in many countries is hindered by a lack of policy clarity, particularly when it comes to their advocacy efforts. In common law countries in particular such as Australia, the US and the UK, vague rules governing what is permissible have had the effect of stifling the voice of many NPOs for fear of overstepping the line between issue campaigning and political campaigning. Recent attempts to change such rules seem to depend more on the political leanings and purposes of the government of the day than the needs of NPOs and the people they intend to serve (Phillips forthcoming).

More generally, the G20 civil society experts consulted by Anheier, Lang, and Toepler (2019) found that

- Few countries have open, proactive dialogues in place to review civil society-government relations; the most common pattern is the absence of any policy engagement, let alone policy contestation or consultation;

- Even fewer countries have reform efforts under way, even though a general sense of reform needs prevails in the opinion of experts;

- Most countries seem to do little to stem the gradual erosion of supportive policy frameworks, perhaps out of unawareness of the need for policy improvements; a lack of civil society activism to push for them and organizational capacity to find a common voice; or the absence of political will on behalf of governments to take action.

France and Canada, however, seem to be the exceptions to this general assessment. Experts agreed that the French government was actively advancing a reform agenda pursuing supply and demand side tools as well as improved regulations, to encourage civil society, the wider social economy, and philanthropy. And in Canada, amid a continued need for reforms, attempts to modernize CSO governance and regulation are underway, with general openness to reform (Anheier, Lang, and Toepler 2019).

\subsection{Regulatory Voids}

Institutions set the "rules of the game" by protecting, policing and enforcing rights and obligations in order to enable cooperation to manage public problems. Yet, the way globalization has progressed in recent decades has challenged the ability to provide and act upon such rules. National governments and international organizations increasingly lack the very institutional capacity needed to legislate, control and enforce regulations (Zürn, Nollkämper, and Peerenboom 2012). The result is the opening of regulatory voids, i. e. the systemic under-institutionalization of policy domains where institutions lack the capacity to deal adequately with the challenges at hand. Migration, finance and taxation, and cyberspace are examples among others of domains lacking appropriate institutional capacity to fill gaping regulatory voids.

As such regulatory voids become apparent, the role of NPOs becomes important: they can mobilize opinion, bring governments and international organizations to impose better rules and play a crucial part in ensuring compliance and implementation by monitoring the behavior of states and economic actors (Malena, Forster, and Singh 2004; Brinkerhoff and Wetterberg 2016). Yet the policy neglect that has resulted in regulatory voids more generally has also created many critical dilemmas for NPOs trying to work within the voids or help close them. Examples include: 
- Migration and refugee rescue operations, e. g. the conflict between humanitarian objectives and EU border protection policies blocking ports for NPO rescue ships in the Mediterranean, threatening criminalization of rescue operations and transferring responsibility for sea rescues to the Libyan coast guard. While NPOs fear the perpetuation of human rights violations through the arrangement with Libya, some European policy makers accuse NPO rescue operations of aiding and abetting human traffickers (Stone 2018). In a similar vein, humanitarian action for illegal migrants along the southern border of the US has recently been subjected to Border Patrol harassment and criminalization (Tomassoni 2019).

- Global finance and taxation, e. g. where NPOs are assuming watchdog roles in exposing tax avoidance by international corporations through tax shaming (Barford and Holt 2013), pointing to the market dangers of quasi-monopolies by leading technology firms (Facebook, Amazon, Netflix and Google), or revealing corrupt procurement practices of international organizations. ATTAC, the Association for the Taxation of Financial Transactions and Citizen's Action, for example, a global network working in this space, has been facing challenges to its public benefit status by German tax authorities because its work as watchdog does not fit neatly into narrow traditional criteria for tax exemption (Diefenbach-Trommer et al. 2018). More broadly, human rights defenders are increasingly threatened by states protecting business interests or business corporations themselves (UN Working Group 2017).

- Cyberspace, e. g. in light of the proliferation of fake news and political influence-seeking through social media and other manipulation, NPOs lead efforts to both promote free expression online and ensure the safety, openness and trustworthiness of cyberspace. The regulatory void associated with cyberspace often pits the rights of free expression and (online) association that are key to civil society's capacity to fulfill its potential against other rights and civil society goals. So long as it is unclear what content is permissible and what is not and what is "issue advocacy" and what is "political campaigning" NPOs will need to walk a fine line.

In these fields and others, actors, including those of civil society, operate within a context of either inadequate regulatory capacity or competing policies and guidance. As a result, the negatives of institutional voids (e. g. moral hazard, regulatory capture, profiteering, and rent-seeking) continue unabated. What is more, institutional voids can widen through contagion effects or deepen by weakening whatever institutions and organizations might exist in the field itself (Anheier and Toepler 2019).

\subsection{Accountability Deficits}

Policy neglect also leaves room for accountability deficits to emerge within the nonprofit sector. As nonprofit organizations have grown in importance domestically and internationally, many have outgrown existing accountability and transparency requirements, structures and, especially, public expectations of actors purportedly serving the public good. This has led in many cases to scandals and to a decline of public trust (when it existed at all).

In recent years, several scandals involving high profile international NPOs have brought to light gaping deficits, especially with regard to the internal accountability mechanisms of NGOs, that is their ability to take responsibility for themselves as opposed to being held responsible externally for meeting standards and obligations (Ebrahim 2003). The investigation of Oxfam International's failure to follow up on charges of sexual abuse involving staff working in Haiti led to revelations of a more general environment that allowed sexual misconduct and bullying to go unchecked throughout the organization constitutes a prime example of the problem (Prakash 2019; Scurlock, Dolsak, and Prakash 2019). Similarly, Amnesty International was forced to close its Zimbabwe office in the wake of rampant fraud and financial mismanagement. On top of this, an investigation following the suicide of two members of its secretariat staff found Amnesty to be a "toxic" workplace, with its leadership failing to hinder bullying and harassment, leading to the eventual resignation of most of its senior leadership team (Ratcliffe 2019). A third example is the revelation that WWF had for years, and with knowledge of its leadership, funded, equipped and trained paramilitary ranger forces in Asian and African parks to combat poaching, which led to rampant human rights abuses, including torture and killings (Warren and Baker 2019). Though NPOs in such cases pledge to enhance staff and beneficiary safeguarding and internal oversight mechanisms, it will take time to rebuild the trust and reputation lost due to such accountability deficits.

Moreover, it directs attention to the need for more effective external accountability mechanisms that are facilitated by transparency rules and practices. In in some countries, such as the US and the UK, calls for more accountability and transparency seem to have reached the nonprofit sector. While trust in NPOs remains relatively high, NPOs and their various umbrella organizations and representatives have for some time supported and implemented accountability and transparency initiatives and mechanisms there.

In many other countries, however, accountability remains limited to fiscal oversight and does not require nonprofits to make their financial statements, funding sources, and results available to the general public. In 
Germany, for example, where NPOs contribute significantly to the functioning of the German welfare state and many receive a generous part of their budgets from public coffers, NPOs remain protected by a tax regime based on tax secrecy that excludes any wider public interest. This makes the German case a prime example of accountability enforcement by a state-led audit regime concentrated on tax requirements. According to the tax code, local tax authorities reward the "nonprofit" status and thus pave the way for tax exemption. However, and this is where it differs from other national regulatory frameworks, all the information gathered in this process falls within the realm of tax secrecy, withdrawing it from broader public scrutiny and deflecting any interest in transparency from stakeholders. As a result, German NPOs operate in a regulatory system with protected secrecy at its core, surrounded by a wide and highly fragmented fringe of specific reporting requirements. In response to this state of affairs, a number of civil society initiatives were launched in recent years, but none has managed to gain much attention (Anheier, Hass, and Beller 2013). The lack of transparency and access in these kinds of external accountability regimes render them less germane to countering internal accountability deficits, making this another key area of policy neglect.

\section{Overcoming Policy Neglect}

The limited and outdated policy approaches and regulatory frameworks at both national and international levels (Phillips and Smith 2011) are a key impediment to enhancing the development of civil society. Without further differentiation, current frameworks whether at national or international levels seem unable to achieve a balance between the interests of governments and civil society that allows the potential of civil society to be realized.

A more differentiated approach to NPOs is clearly needed. It must go beyond the one-size-fits-all of current regulatory frameworks, which are largely based on conventional notions of charity and public utility. They are rooted in outdated notions of how organizations should serve the public good, and they fail to consider the diversity of modern organizational forms and ways of collective action. Instead, frameworks should be based on the functional differentiation embodied in the policy perspectives above, taking into account organizational forms, comparative advantages and drawbacks. As laid out in (author citation) and summarized in Table 1, we have proposed a number of these differentiations.

Table 1: Nonprofit roles, predominant legal forms, and related regulatory issues.

\begin{tabular}{|c|c|c|}
\hline Role & Legal Form & Issues for Regulation \\
\hline \multirow[t]{3}{*}{ Service Provision } & Corporation & Donative vs. vendor vs. commercial NPOs \\
\hline & & Blurring nonprofit/for-profit boundary \\
\hline & & Capital access and hybrid forms \\
\hline \multirow[t]{3}{*}{ Civic engagement } & Association & Member vs. public serving; accountability \\
\hline & & Degrees of publicness vs. privateness \\
\hline & & Advocacy and lobbying vs. partisan political activity \\
\hline \multirow[t]{2}{*}{ Financial Intermediation } & Foundation & Role definition and expectations \\
\hline & & Legitimacy in public policy process \\
\hline \multirow[t]{2}{*}{ Social Innovation } & Any form & Vetting and scaling social innovation \\
\hline & & Development of social investment markets and social \\
\hline
\end{tabular}

\subsection{Service Providers}

Perhaps first and foremost, new regulatory frameworks would usefully introduce distinctions among nonprofits in the role of service providers. Necessary differentiations would distinguish the treatment of truly charitable, donative nonprofits from those acting as government vendors primarily delivering contracted services in public-private partnership and quasi-market arrangements with competitive tendering. These could be further differentiated from commercialized nonprofits competing with for-profits and some public agencies in mixed industries. Nonprofits in these industries typically face resource issues, while their tax-exempt status limits their ability to fully deploy business methods. In either case, service-providing nonprofits typically take the form of corporations rather than membership-based associations to speed up and streamline decision-making and because of liability considerations where significant assets are involved. But even in corporate form, nonprofits face severe limits in their ability to access capital markets for investments or to offer competitive compensation 
packages due to their tax status. As a result, nonprofits have long probed their regulatory boundaries through growing commercialization (Weisbrod 1998; Eikenberry and Kluver 2004).

The main regulatory challenge here is to devise feasible oversight mechanisms to contain the blurring boundaries between the for-profit and nonprofit sectors, which should also include regulatory workarounds to facilitate capital markets access beyond the narrow and limited options for accessing tax-exempt bond financing that often only few charities can tap into. Over the past decade or so, new hybrid legal forms have been proposed and developed in efforts to solve some of these capitalization problems, which in and by itself supports our call formore differentiated regulatory systems. The L3C and the benefit corporation in the US or the public benefit corporation in the UK are so far the main attempts at addressing the shortcomings of both the nonprofit and for-profit forms (Brewer 2016; Abramson and Billings forthcoming), but whether they'll prove suitable alternative options to remedy problems with nonprofits is still far from being established (Toepler 2018c).

\subsection{Civic Engagement}

While some service providers also conduct advocacy to increase the impact and effectiveness of their work for clients (cf. Abramson, Benjamin, and Toepler 2014), citizen engagement and the performance of the advocacy and value guardian roles have traditionally been the purview of nonprofits organized as associations. From a regulatory perspective, key issues here involve differentiating between primarily public- vs. member-serving activities as well as ensuring accountability. Although nonprofits/NGOs have now for decades been pushed as means to achieve democratization goals, the consensus about their democratization role is beginning to erode. Questions are increasingly asked about the degree to which nonprofits actually represent their communities or even their members. This happens at both local and global levels (Brechenmacher and Carothers 2018). Long seen by neo-Toquevilleans as schools of democracy, active association membership, and with it the participation of members in organizational governance and internal decision-making, appears to be declining.

For economic and other associations focused on generating specific benefits for members (Salamon and Sokolowski 2016), the production of private benefits raises questions about special interest motives and the justification of beneficial tax treatment. Regulatory frameworks ought to recognize different degrees of publicness versus privateness of the benefits generated by associations: associations that primarily serve public purposes should be eligible for greater tax benefits and other concessions than those that exclusively serve their members' interests. Among the more thorny issues is the intersection of political party financing which should be treated separately in any regulatory framework, including various nonprofit-like vehicles that seek to divert private funds into campaigns and politics.

Regulating non-partisan political activities, especially advocacy and lobbying, raises its own set of separate concerns, particularly in the Anglo-Saxon world. In the American case, rules on lobbying have historically been extremely vague providing an opening for the government to potentially exercise a degree of discretion in imposing severe tax penalties for violations. Given the risks involved, charities tend to shy away from engaging in even perfectly legitimate advocacy activities. Regulatory frameworks need to be attuned to the civil society vs. party politics boundary and make clear and consistent distinctions between legitimate political activity and undue partisan involvements.

Civic engagement also includes having nonprofits along with web-based advocacy platforms engage in enforcing social accountability vis-à-vis governmental programs and initiatives (Fox 2015; Brinkerhoff and Wetterberg 2016). Yet, enforcing accountability in the public sector places extra expectations on nonprofits in this role to be unassailably on top of their own transparency and accountability relationships to avoid being branded as pursuers of special interests. Strict accountability and transparency standards and an appropriate sanction and enforcement regime - whether public or self-regulated-is needed (Ebrahim and Weisband 2007; Gugerty and Prakash 2010).

\subsection{Financial Intermediaries}

Yet different are the regulatory needs for financial intermediation, or the private support for the public good. While this now takes place in many different avenues, including federated campaigns and increasingly donor-advised funds administered by investment firms, the classic form associated with this role is the philanthropic foundation. Grantmaking foundations are often seen as special institutions, because their endowments composed of income-producing assets grants them a degree of freedom from external control, be it ownership or an electorate. Arguably, foundations therefore enjoy a dual independence from market and political considerations that sets them principally free to tackle complex, controversial, and even unpopular issues, assume long-term 
perspectives and pursue solutions with high risk of failure, but also high potential payoffs. Foundations are thus theoretically in position to pursue a set of special roles, such as the pursuit of change and innovation, the redistribution of wealth, the building of societal infrastructure and generally complementing or substituting for government action (Anheier and Hammack 2010; Anheier and Leat 2018). However, governments frequently focus less on these potentials of foundations and rather see them as convenient 'cash machines' or sources of private support to fill public funding gaps (Abramson, Soskis, and Toepler 2014; Toepler 2018b). In navigating these divergent role expectations, foundations face fundamental legitimacy concerns as private actors attempting to impact public policy agendas (Heydemann and Toepler 2006).

\subsection{Social Innovators}

A final regulatory differentiation relates to the vanguard role or social innovation, which is less associated with a particular organizational form than the other roles. While evidence suggests that nonprofits do pursue innovation in the vanguard function, the replicability, diffusion and scaling up of innovations poses significant challenges for them (Anheier et al. 2017). So far, systematic screening and vetting systems for social innovations are not in place, and inadequate dissemination and information-sharing often are major contributors to the failures of promising approaches. Consequently, small-scale, yet successful social innovations fail to attract support and do not get picked up, leading to waste and unnecessary duplications of effort.

Even innovations that find resonance and make it through the initial stages often stay below their full potential, as there are not yet any social investment markets that would be able to provide resources needed to take innovations to scale. Impact bonds, crowdfunding platforms and related emerging instruments are pointing in the right direction (Albertson et al. 2018; Han, Chen, and Toepler forthcoming), but still fall short. The regulatory and policy challenge that presents itself here is the creation of a platform or clearinghouse to systematically assess social innovation potential and establish a suitably regulated social investment market.

\section{Conclusion}

Civil society, challenged in many ways, yet harboring huge potential, finds itself at a crossroads in most countries around the world. In this article, we have argued that the key challenge is not just combatting the global closing of the civic space, but that the phenomenon of growing policy neglect that has largely flown below the radar so far also urgently needs policy attention. Nonprofits have long outgrown their regulatory frameworks, and it is up to policymakers to provide adequate environments. The policy challenge is clear: What is the right policy framework to balance the interests of civil society and government, while realizing the potential of civil society and taking into account the functional differences among nonprofits and the various organizational forms underlying them?

All of these issues require fundamental debate considering the longer-term trajectories of government-civil society relations. They are likely to lead to preferences for different, and hopefully also improved, regulatory frameworks. Perhaps one reason for the often contradictory policy environments for NPOs, and the policy neglect they have encountered and are encountering, is that these long-term first-order governance decisions have been left unattended, even avoided, for too long.

\section{Notes}

1 Parts of the introduction and section 3 of this paper draw on Anheier, Lang, and Toepler (2019) and policy briefs prepared for T20 meetings in Germany and Japan in 2018 and 2019.

2 Among those are Hungary, Israel and Turkey. Even the United States is not entirely immune, as evidenced in the reproductive rights arena with the continuous reemergence of the Mexico City policy (also referred to as global gag rule) and the ongoing efforts to defund Planned Parenthood (Toepler 2018a: 415-16). Simsa (2019) diagnoses similar tendencies in Austria.

\section{References}

Abramson, A., L. Benjamin, and S. Toepler. 2014. “Metro TeenAIDS: Serve and Advocate." In Cases in Innovative Nonprofits: Organizations that Make a Difference, edited by R. Cnaan, and D. Vinokur-Kaplan, 229-242. Thousand Oaks: Sage. 
Abramson, A., and C. Billings. forthcoming. "Hybrid Organizations." In Routledge Companion to Nonprofit Management, edited by H. K. Anheier, and S. Toepler. London: Routledge.

Abramson, A., B. Soskis, and S. Toepler. 2014. “Public-philanthropic Partnerships: A Review of Recent Trends.” The Foundation Review 6 (2). https://doi.org/10.9707/1944-5660.1201.

Albertson, K., C. Fox, C. O'Leary, and G. Painter. 2018. Payment by Results and Social Impact Bonds: Outcome-based Payment Systems in the UK and US. Bristol: Policy Press.

Anheier, H. K. 2014. Nonprofit Organizations: Theory, Management, Policy. London: Routledge.

Anheier, H. K. 2017. “Civil Society Challenged: Towards an Enabling Policy Environment." Economics: The Open-Access, Open-Assessment EJournal 11 (2017-29): http://dx.doi.org/10.5018/economics-ejournal.ja.2017-29.

Anheier, H. K., and D. C. Hammack. 2010. American Foundations: Roles and Contributions. Washington, DC: Brookings Institution Press.

Anheier, H. K., R. Hass, and A. Beller. 2013. "Accountability and Transparency in the German Nonprofit Sector." A Paradox? International Review of Public Administration 18 (3). https://doi.org/10.1080/12294659.2013.10805264.

Anheier, H. K., G. Krlev, G. Mildenberger, and C. Behrendt. 2017. Directions for Policy Makers - How to Support and Engage in Social Innovation. ITSSOIN Policy Brief, Brussels: European Commission, DG Research.

Anheier, H. K., M. Lang, and S. Toepler. 2019. “Civil Society in Times of Change: Shrinking, Changing and Expanding Spaces and the Need for New Regulatory Approaches." Economics 13 (2019-8). http://dx.doi.org/10.5018/economics-ejournal.ja.2019-8.

Anheier, H. K., and D. Leat. 2018. Performance Measurement in Philanthropic Foundations: The Ambiguity of Success and Failure. Oxford: Routledge.

Anheier, H. K., and S. Toepler. 2019. Civil Society and the G20: Towards a Review of Regulatory Models and Approaches. Policy Brief for T2O, Japan, 2019. https://t2ojapan.org/wp-content/uploads/2019/03/t20-japan-tf6-10-civil-society-g20.pdf.

Barford, V., and G. Holt. 2013. Google, Amazon, Starbucks: The Rise of 'tax Shaming.' BBC News Magazine, May 2013. https://www.bbc.com/news/magazine-20560359.

Brandsen, T. forthcoming. "Co-production." In The Routledge Companion to Nonprofit Management, edited by H. K. Anheier, and S. Toepler. London: Routledge.

Brechenmacher, S., and T. Carothers. 2018. Examining Civil Society Legitimacy. Available at: https://carnegieendowment.org/2018/05/02/examining-civil-society-legitimacy-pub-76211.

Brewer, C. V. 2016. “The Ongoing Evolution in Social Enterprise Legal Forms." In The Social Enterprise Zoo: A Guide for Perplexed Scholars, Entrepreneurs, Philanthropists, Leaders, Investors, and Policymakers, edited by D. R. Young, E. A. M. Searing, and C. V. Brewer, 33-64. Cheltenham: Edward Elgar Publishing.

Brinkerhoff, D. W., and A. Wetterberg. 2016. "Gauging the Effects of Social Accountability on Services, Covernance, and Citizen Empowerment." Public Administration Review 76 (2): 274-86. https://doi.org/10.1111/puar.12399.

Carothers, T., and S. Brechenmacher. 2014. Closing Space: Democracy and Human Rights Support under Fire. Carnegie Endowment for International Peace. https://carnegieendowment.org/files/Brief-Carothers-Closing_Space.pdf.

Civicus. 2018. State of Civil Society Report 2018. Available at: https://www.civicus.org/index.php/state-of-civil-society-report-2018.

Daigle, D., S. Toepler, and S. Smock. 2016. Financial Access for Charities Survey 2016: Data Report to the Charity and Security Network Version 1.1. Arlington, VA: Ceorge Mason University. https://doi.org/10.13140/RG.2.2.15604.60806.

Diefenbach-Trommer, S., J. Marré, J. Klugkist, and M. Schmidt. 2018. Engagiert Euch-Nicht? Wie Das Cemeinnützigkeitsrecht Politisches Engagement Erschwert. BBE Working Paper \#5. Berlin: Bundesnetzwerk Bürgerschaftliches Engagement.

Dupuy, K., J. Ron, and A. Prakash. 2016. “Hands off My Regime! Governments' Restrictions on Foreign Aid to Non-governmental Organizations in Poor and Middle-income Countries." World Development 84: 299-311.

Ebrahim, A. 2003. “Accountability in Practice: Mechanisms for NCOs." World Development 31 (5): 813-29.

Ebrahim, A., and E. Weisband. 2007. Clobal Accountabilities: Participation, Pluralism, and Public Ethics. Cambridge University Press. https://doi.org/10.1017/CBO9780511490903.

Eckert, S., K. Guinane, and A. Hall. 2017. Financial Access for U.S. Nonprofits. Washington: Charity \& Security Network.

Eikenberry, A. M., and ]. D. Kluver. 2004. “The Marketization of the Nonprofit Sector: Civil Society at Risk?” Public Administration Review 64 (2): $132-40$.

Fox, J. A. 2015. “Social Accountability: What Does the Evidence Really Say?” World Development 72: 346-61. https://doi.org/10.1016/j.worlddev.2015.03.011.

Gugerty, M. K., and A. Prakash. 2010. Voluntary Regulation of NCOs and Nonprofits: An Accountability Club Framework. Cambridge: Cambridge University Press.

Han, J., W. Chen, and S. Toepler. forthcoming. "Social Finance for Nonprofits." In Routledge Companion to Nonprofit Management, edited by H. K. Anheier, and S. Toepler. London: Routledge.

Heydemann, S., and S. Toepler. 2006. "Foundations and the Challenge of Legitimacy in Comparative Perspective." In The Legitimacy of Philanthropic Foundations: U.S. And European Perspectives, edited by K. Prewitt, M. Dogan, S. Heydemann, and S. Toepler. New York: Russell Sage Foundation.

ICNL. 2018. Civic Freedom Resources. International Center for Nonprofit Law. Available at: http://www.icnl.org/research/resources/index.html.

Malena, C., R. Forster, and J. Singh. 2004. Social Accountability an Introduction to the Concept and Emerging Practice. Social Development Paper No. 76. Washington: World Bank.

Phillips, S. forthcoming. "A Changing Management Context: The US, UK, Canada and Australia," In The Routledge Companion to Nonprofit Management, edited by H. Anheier, and S. Toepler. London: Routledge.

Phillips, S., and S. R. Smith. 2011. Covernance and Regulation in the Third Sector: International Perspectives. London: Routledge.

Prakash, A. 2019. "Nonprofit Covernance, Public Policy, and the Oxfam Scandal: An Introduction." Nonprofit Policy Forum 10: 4.

Putnam, R. D. 2001. Bowling Alone: The Collapse and Revival of American Community. New York: Simon \& Schuster. 
Ratcliffe, R. 2019. Amnesty International Leaders Offer to Resign over Bullying Culture. The Guardian, February 22, 2019. https:/www.theguardian.com/global-development/2019/feb/22/amnesty-international-leaders-offer-to-resign-over-bullyingworkplace-culture.

Salamon, L. M., and S. W. Sokolowski. 2016. “Beyond Nonprofits: Re-conceptualizing the Third Sector." International Journal of Voluntary and Nonprofit Organizations 27 (4): 1515-45. https://doi.org/10.1007/s11266-016-9726-Z.

Salamon, L. M., and S. Toepler. 2015. “Covernment-nonprofit Cooperation: Anomaly or Necessity?” International Journal of Voluntary and Nonprofit Organizations 26 (6): 2155-77. https://doi.org/10.1007/s11266-015-9651-6.

Scurlock, R., N. Dolsak, and A. Prakash. 2019. "Recovering from Scandals: Twitter Coverage of Oxfam and Save the Children Scandals." Voluntas. https://doi.org/10.1007/s11266-019-00148-x.

Simsa, Ruth. 2019. "Civil Society Capture by Early Stage Autocrats in Well-Developed Democracies - The Case of Austria." Nonprofit Policy Forum 10 (3). https://doi.org/10.1515/npf-2019-0029.

Stone, Jon. 2018. EU condemns rescue boats picking up drowning refugees in Mediterranean as leaders side with populists: The European Union has backed the policy of Italy's new populist government on the vessels. The Independent, 29 June 2018. https://www.independent.co.uk/news/world/europe/eu-migrant-crisisrescue-boats-refugees-drowning-charity-mediterraneana8423261.html.

Strachwitz. 2018. Rupert Bekommen wir endlich eine Reform des Cemeinnützigkeitsrechts? Newsletter für Engagement und Partizipation in Deutschland 11/2018 2018

Toepler, S. 2018a. “Covernment Funding Policies." In Handbook of Research on Nonprofit Economics and Management, 2nd ed. edited by B. Seaman, and D. Young, 409-427. Cheltenham: Edward Elgar.

Toepler, S. 2018b. "Public Philanthropic Partnerships: The Changing Nature of Covernment/Foundation Relationships in the US." International Journal of Public Administration 41 (8): 657-69. https://doi.org/10.1080/01900692.2017.1295462.

Toepler, S. 2018c. “Do Benefit Corporations Represent a Policy Threat to Nonprofits?” Nonprofit Policy Forum 9 (4). https://doi.org/10.1515/npf2018-0021.

Tomassoni, T. 2019. Activists Making 'water Drops' for Migrants near Border Say Covernment Intimidation Is Rising. The Washington Post, January 29, 2019. https://www.washingtonpost.com/national/activists-making-water-drops-for-migrants-near-southern-border-saygovernment-intimidation-is-rising/2019/01/29/1f832464-1f52-11e9-8b59-0a28f2191131_story.html?utm_term=.889ccod39fd3.

UN Working Group on Business and Human Rights. 2017. Human Rights Defenders and Civic Space: The Business \& Human Rights Dimension. (Informal Background note) https://www.ohchr.org/Documents/Issues/Business/ForumSession6/UNWG_ProjectHRDsBackgroundNote12052017.pdf.

Verschuere, B., T. Brandsen, and V. Pestoff. 2012. "Co-production: The State of the Art in Research and the Future Agenda." International Journal of Voluntary and Nonprofit Organizations 23 (4): 1083-101. https://doi.org/10.1007/s11266-012-9307-8.

Warren, T., and K. Baker. 2019. "WWF's Secret War: WWF Funds Cuards Who Have Tortured and Killed People." BuzzFeed News https://www.buzzfeednews.com/article/tomwarren/wwf-world-wide-fund-nature-parks-torture-death.

Weisbrod, B. 1998. To Profit or Not to Profit: The Commercial Transformation of the Nonprofit Sector. Cambridge: Cambridge University Press.

Zürn, M., A. Nollkämper, and R. Peerenboom, eds. 2012. Rule of Law Dynamics: In an Era of International and Transnational Covernance. Cambridge: Cambridge University Press. 